\title{
Donald L. Morton
}

(1934-2014)

Zmarł Donald L. Morton, jeden z największych autorytetów w onkologii.

Morton zaproponował procedurę biopsji węzła chłonnego wartowniczego u chorych na czerniaka i w ten sposób zmienił całą filozofię leczenia chirurgicznego chorych na nowotwór. Przedstawianie zasług Donalda Mortona dla światowej onkologii byłoby w stosunku do Niego nietaktem, ponieważ każda praca naukowa, jaka ukazuje się w światowym piśmiennictwie, dotycząca biopsji węzła chłonnego wartowniczego, odwołuje się do Jego artykułu

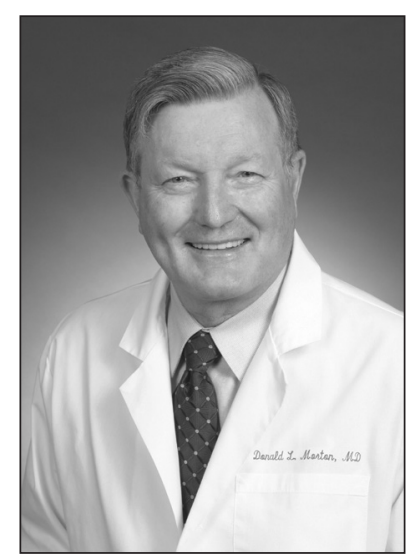
z 1992 roku. Już za życia stał się legendą. W swoim środowisku jako naukowiec był podziwiany, a jako człowiek — uwielbiany.

Charles M. Balch, profesor chirurgii w John Hopkins Hospital w Baltimore, w 2011 roku na łamach Journal of Surgical
Oncology napisał o Mortonie tak: „Donald Morton is truly a legend in surgical oncology, an icon as a surgical investigator, a pioneer in melanoma, a valued mentor, an authentic role model and a cherished friend to many of us around the world".

Donald Morton odwiedził również Polskę - przyjął moje zaproszenie do Łodzi na XII Zjazd Polskiego Towarzystwa Chirurgii Onkologicznej w 2006 roku. Wygłosił wówczas wykład inauguracyjny, a w pierwszym dniu obrad wygłosił dwa wykłady tematyczne. Otrzymał Członkostwo Honorowe Polskiego Towarzystwa Chirurgii Onkologicznej.

Zapisał się w mojej pamięci jako człowiek otwarty i serdeczny, zarazem zwyczajny i niezwykły.

Prof. dr hab. n. med. Arkadiusz Jeziorski

Klinika Chirurgii Onkologicznej

Uniwersytet Medyczny w Łodzi

e-mail:jeziorski@post.pl 